\title{
The Meiji Restoration
}

W. G. Beasley. For Japan the Meiji Restoration of 1868 is the point from which modern history begins. A complicated affair, it was difficult to understand at the time and has been subject to controversy ever since. This work offers the first modern, full-scale account of the origins, development, and immediate aftermath of the Restoration in any Western language. In it the author sees the Restoration's origins not in economic distress or class struggle, but in a growing sense of national danger and national pride spurred by Japan's contacts with the West. Nationalism provided the impetus for overthrowing the Tokugawa. Only when the Tokugawa were gone did their successors turn of necessity to the making of modern Japan, seeking strength and stability in new social patterns. $\$ 17.50$

\section{Every Fifth Child}

\section{The Population of China}

Leo A. Orleans. It is generally accepted that China has about one-fifth of the world's population within her borders. Considering how little reliable information is available, this is as definitive a statement as one can make. And yet more precise estimates of the size, structure, and rate of growth of this population are essential to an understanding of China's current problems and policies. This study tries to tell the story of China's population: a little about what it was, but mostly about what it is and what we know and don't know about it. The author follows his subject into areas where policy and daily life coincide: the schools, farms, and factories of a nation that faces gigantic problems of urbanization, technological education, and manpower. $\$ 8.50$

\section{Stanford University Press}




\section{journal of social history}

Editor: Peter N. Stearns

An interdisciplinary publication focusing on the development of basic concepts and techniques.

Elizabeth Peck The Two-Parent Household: Black Family Structure in Late Nineteenth Century Boston

Dee Garrison The Tender Technicians: The Feminization of Public Librarianship

Daniel Horn Youth Resistance in the Third Reich: A Social Portrait

T.H. Breen A Changing Labor Force and Race Relations in Virginia, 1660-1710

David Pinkney The Revolutionary Crowd in Paris in the 1830s

The only English-language journal specializing exclusively in the field of social history.

Four issues annually.

Subscription rates: $\$ 12.50$ per volume year (full-time students: s8.). Single copies: $\$ 5$. Foreign: $\$ 14$ per year.

Mail subscription orders to:

JOURNAL OF SOCIAL HISTORY

Transaction Periodicals Consortium

Box A, Rutgers University

New Brunswick, N.J. 08903 


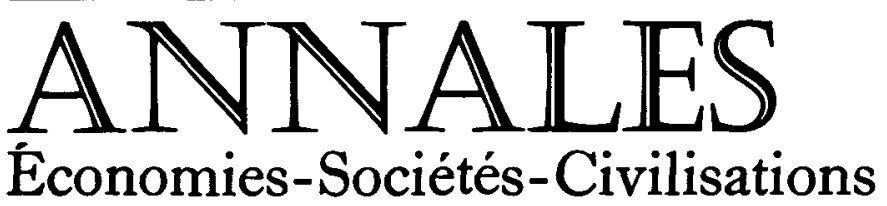

Revue bimestrielle, fondée en I929 par Lucien FEBVRE et Marc BLOCH

Comité de Direction: Fernand BRAUDEL, Marc FERRO, Georges FRIEDMANN, Jacques LE GOFF, Emmanuel LE ROY LADURIE, Charles MORAZE

Secrétaire du Comité: Paul LEUILLIOT Secrétaire de la Rédaction: André BURGUIÈRE

27e ANNEE-No. 6

NOVEMBRE-DECEMBRE 1972

OUTILLAGE

L. GENICOT La typologie des sources du Moyen Age occidental INTER-SCIENCES

A. et J. GORDUS, E. LE ROY LADURIE, D. RICHET Le Potosi et la physique nucléaire

FRONTIËRES NOUVELLES

G. OUY et K. OUY PARCZEWSKA Les origines des règles de l'art

DEBATS ET COMBATS

M. de CERTEAU Une épistémologie de transition: Paul Veyne

FAMILLE ET SOCIETÉ

R. TREXLER Le célibat à la fin du Moyen Age: les religieuses de Florence

R. SCHNUCKER La position puritaine à l'égard de l'adultère

J. L. FLANDRIN Mariage tardif et vie sexuelle: discussions et hypotheses de recherche.

NOTES CRITIQUES

J. DELUMEAU Démographie et mentalités: la mort en Anjou (XVIIe-XVIIIe siècle)

P. SOUYRI Variations sur le marxisme

COMPTES RENDUS Marxismes et marxistes

LES DOMAINES DE L'HISTOIRE

G. MAUDUECH La "bonne" ville: origine et sens de l'expression

J.-P. GENÊT Economie et société rurale en Angleterre au XVe siècle d'après les comptes de l'Hôpital d'Ewelme

C. PONI Archéologie de la fabrique: la diffusion des moulins à soie "alla bolognese" dans les Etats vénitiens, du XVe au XVIIIle siècle

B. JOACHIM Commerce et décolonisation. L'expérience franco-haïtienne au XIXe siècle

Rédaction: 54, Boulevard Raspail, 75006-Paris

Administration: Librairie Armand COLIN, 103 Boulevard Saint Michel, 75005Paris

Comptes Chèques Postaux: PARIS, N॰21 335-25

Abonnements 1973: France et Union Française: 60 F. Etranger: 75 F.

Le numéro: 13 F. Numéros spéciaux (double): 26 F. 


\section{STUDI STORIGI}

SOMMARIO de/ n. 3-1972

- R. Faucci

TEORIA E POLITICA AMMINISTRATIVA NELl'ItALIA LIBERALE: PROBLEMI APERTI

- M. Degl'Innocenti

LA GUERRA LIBICA, LA CRISI DEL RIFORMISMO E LA VIT. TORIA DEGLI INTRANSIGENTI

- L. Whitehead

LA GRANDE CRISI IN BOLIVIA

OPINIONI E DIBATTITI

- K. Jäcklein

FALSIFICAZIONI ETNOGRAFICHE E REALTA SOCIALE. LA FAMIGLIA IN UN MUNICIPIO MESSICANO

PROBLEMI DI RICERCA

- G. Barone

SVILUPPO CAPITALISTICO E POLITICA FINANZIARIA IN ITALIA NEL DECENNIO 1880-1890

DOCUMENTI

- N. Siciliani de Cumis

NOTE SU ANTONIO LABRIOLA

NOTE CRITICHE-CRONACHE

\section{ABBONATEVI}

Riceverete in omaggio una cartella con 8 disegni di autori vari

\section{Un fascicolo L. 1.500}

Comitato direttivo- Giuliano Procacci, Ernesto

Ragionieri, Rosario Villari, Renato Zangheri

Direzione e Redazione: Bologna, Via Barberia $4^{2}$

AMMINISTRAZIONE: ROMA, Via Frentani, 4

Abbonamenti : anno L. 5.000 estero L. 8.500, un fascicolo L. 1.500

Versamenti : S.G.R.A. - Via dei Frentani, 4 - c/c p. n. 1/43461 


\section{MINER VA}

\section{A REVIEW OF SCIENCE, LEARNING AND POLICY}

EDITOR: EDWARD SHILS

VOL. $x$, No. 4

OCTOBER 1972

COMMENT

The Invitation to Caesar

ARTICLES

Research for Policy

David Donnison

The Argument for the Self-Government and Public

Support of Science in Weimar Germany

Brigitte Schroeder-Gudehus

Criteria of Choice in Social Science Research

Harold Orlans

DISCUSSION

Some Practical Problems of Scientist-Advisers

Rodney $W$. Nichols

REPORTS AND DOCUMENTS

The Wider Setting of Disorder in the German Universities

Helmut Schelsky

BOOK REVIEWS

Juan Linz, William K. Cummings

Annual subscription: $£ 3.50 / \$ 10.50$

Single copy: $£ 1.00 / \$ 3.00$

MineRva, 59 St. Martin's Lane, London WC2N 4JS. 


\title{
the australian journal of POLITICS \\ AND \\ HIS T O R Y
}

The Federal Convention, an analysis of the voting

P. Loveday

Protecting Polish interests in the USSR 1943-1944:

an episode in Australian representation

P. Heydon

Prolegomena to the study of Democracy

D. M. White

French loans to China 1895-1914: The alliance of international finance and diplomacy

D. Gagnier

Historians and Australian Railways

P. N. Lamb

\begin{abstract}
AUSTRALIAN POLITICAL CHRONICLE BOOK REVIEWS
\end{abstract}

$$
\text { Price } \$ 4.00
$$

Registered in Australia for transmission by post as a book

PUBLISHED THREE TIMES YEARLY

\section{UNIVERSITY OF QUEENSLAND PRESS}




\title{
SURVEY
}

\section{A Journal of East and West Studies}

\section{Volume 18 No. 4 (85)}

\section{Autumn 1972}

\section{JAPAN AT THE CROSSROADS}

Willard Barber

Shinkichi Eto

Ivan P. Hall

Rinjiro Harako

G. F. Hudson
Fuji Kamiya

Richard Löwenthal

Wolf Mendl

Osamu Miyoshi

Mitsuro Muto

Saburo Okita

\section{MOSCOW CORRESPONDENT}

David Bonavia

Per Egil Hegge

\author{
Annual subscription $£_{3}$ or US $\$ 8$ \\ Student subscription $£_{1} \cdot 50$ or US $\$ 4$ \\ Single copies: $75 \mathrm{P}$ or US $\$ 2$
}

Editorial office: Ilford House, I 33 Oxford Street, London WI R ITD

Subscription office: Oxford University Press, Press Road, Neasden, London NWIo oDD

vii 


\section{Journal of Social Issues}

\section{2}

Volume 28

Number 3

\section{Positive Forms of Social Behavior Issue Editor: Lauren G. Wispé}

Positive Forms of Social Behavio

Altruism: Human, Cultural, or What? Joseph Katz

....Ronald Co hen

Why Children Help: A Review.

Donald T. Campbeil

..........James H. Bryan

Individual Orientations to Prosocial Behavior..........Kenneth J. Gergen, Mary K. Gergen, and Kenneth Meter

Learning Theory and Prosocial Behavior ................................ L. Rosenhan Promotive Tension: The Basis of Prosocial Behavior from a Lewinian Perspective

Harvey A. Hornstein

Equity and the Innocent Bystander.....................Elaine Walster and Jane Allyn Piliavin Psychoanalysis and Education for the Facilitation of Positive Human Qualities.....................
Rudolph Ekstein Instigation to Goodness: The Role of Social Norms and Interpersonal Infiuence. E............. A Legal look at Prosocial Behavior: What Can Happen for Failing to Help or Trying to Help
Someone........................................................................................ John Kaplan Someone. Biographical Sketches

Order from:

Journal of Social Issues

P.O. Box 1248

Ann Arbor, Michigan 48106

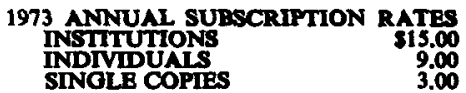

Published Quarterly by

THE SOCIETY FOR THE PSYCHOLOCICAL STUDY OF SOCIAL ISSUES

(a division of the American Paychological Association) 
Comparative Studies in Society and History is a forum for presentation and discussion of new research into problems of change and stability that recur in human societies through time or in the contemporary world. It sets up a working alliance between specialists in all branches of the social sciences and humanities. Debate and review articles bring the general reader in touch with current findings and issues.

\section{NOTES FOR CONTRIBUTORS}

Contributions may be descriptive, analytical or theoretical. Any article not in itself comparative may be accepted if it lends itself to comment that will place it in comparative perspective. Correspondence with the editors prior to the submission of articles will help to enable them to obtain such comment or a companion study. Emphasis in comparative studies may be either on similarities or, if these are significant enough and call for some recasting of generalisations, on differences. All contributions and editorial correspondence should be sent to the Editors, Comparative Studies in Society and History, Department of History, University of Michigan, Ann Arbor, Michigan 48104.

Two copies of each contribution, preferably accompanied by a stamped, addressed envelope, should be submitted. Both text and footnotes should be clearly typed with double spacing and wide margins; footnotes should appear on separate pages at the end of the article. Illustrations may be included by arrangement with the editors.

Contributors will receive 50 offprints bound in the journal covers. Any additional offprints must be ordered on receipt of the first proof. 


\section{COMPARATIVE STUDIES IN SOCIETY AND HISTORY}

Editorial Foreword

Counter-Culture

MARTIN SCHIFF Neo-transcendentalism in the New Left

Counter-Culture: A Vision of the Future Looking Back

$130-142$

Religious Reformations

Sheldon Shapiro Patterns of Religious Reformations

$143-157$

Rural Social Structures

Wolfram Fischer Rural Industrialization and Population Change

John Stuart Macdonald and Leatrice D. MacDONALD Transformation of African and Indian Family Traditions in the Southern Caribbean

\section{Modernization}

Dean C. TIPPS Modernization Theory and the Study of National Societies: A Critical Perspective

Review Articles

Pamela J. Utz Evolutionism Revisited

James A. VANn The Comparative Method and German Urban History 240-248

MYRON WEINER National Integration vs. Nationalism 248-254

Books Received

Cambridge University Press

Bentley House, 200 Euston Road, London NW1 2DB American Branch: 32 East 57th Street, New York, N.Y. 10022 $£ 2.00$ net in U.K.; $\$ 5.00$ in U.S.A. Subscription price $£ 5.00$ net in U.K.; $\$ 14.00$ in U.S.A. at the Alden Press, Oxford 